\title{
Carl Lavery
}

\section{The Pepys of London E11: Graeme Miller and the Politics of Linked}

\begin{abstract}
In 2003, Graeme Miller was commissioned by the Museum of London to produce a sitespecific artwork for its oral history collection. Miller responded by creating Linked, a performance which bears witness to the disastrous impact the M11 link road has had on his local neighbourhood since its construction in the 1990s. Helped by a team of researchers, Miller interviewed local citizens and road protesters and broadcast their testimonies from twenty transmitters that line the route of the link road. In order to activate the work, the participant borrows a headset from a local library and is invited to follow the link road from Hackney to Wanstead, a distance of roughly four miles. This article explores the politics of Linked from a number of different theoretical perspectives: contemporary ethnography, everyday life studies, urban theory, and Situationism. The objective is to show that Linked offers an alternative paradigm for political performance - a paradigm which also necessitates an idiosyncratic and subjective form of writing. The article is followed by an interview in which Miller speaks about the processes involved in making Linked. Carl Lavery teaches performance and theatre at Loughborough University.
\end{abstract}

Artists are meant to be that bit more resourceful, that bit better at lateral thinking, quicker to react, and they could have a useful role to play in the tiny acts of micropolitics that make a difference to the macropolitics that make a difference.

Graeme Miller $^{1}$

Returning theatre to its urban context allows us to consider its function within a modern and contemporary urban practice.

Stanton B. Garner, $\mathrm{Jr}^{2}$

If he loves justice ... the 'scholar' of the future, the 'intellectual' of tomorrow should learn it and from the ghost. He should learn to live by learning not how to make conversation with the ghost but how to talk to him, with her, how to let them speak or to give them back speech, even if it is in oneself, in the other, in the other in oneself; they are always there, spectres, even if they do not exist, even if they are no longer, even if they are not yet.

Jacques Derrida ${ }^{3}$

Today everyone who values cities is disturbed by automobiles.

Jane Jacobs ${ }^{4}$

ALTHOUGH his practice resists easy definition, combining playwriting, composing, walking, and sonic installation art, Graeme Miller is consistent in his attempts to use performance as a barometer of the everyday, a way of gauging the temperature of the times. Much of his work is interventionist in a direct, site-specific sense. He has installed sound observatories to record what the Marxist philosopher Henri Lefebvre calls 'the music of the city'; $;$ ' collaborated with the inhabitants of these cities by making work from their experiences of space; and sent his audience (if we can still use that worn-out word in this context) on guided walks through a variety of urban landscapes.

Miller's interest in the city as a site of performance has much in common with contemporary currents in ethnology and sociology. In this essay I want to explore those parallels by focusing on Linked, ${ }^{6}$ an on-going work that was commissioned by the Museum of London as part of its urban art collection in 2003. ${ }^{7}$ The essay unfolds in three stages. In the first, I relate Miller's performance practice to developments in urban theory, paying particular attention to the concept of everyday life as theorized by Henri Lefebvre and Michel de Certeau. In the second, I provide a performative account of my experience of walking Linked in the summer of 2004. ${ }^{8}$ In the third stage, I argue that Linked offers an alternative paradigm for political performance. 


\section{Siting Linked}

Linked is part of a series of multi-disciplinary works on the city that Miller, a founding member of the influential Impact Theatre Co-operative, has been producing for more than a decade. These include The Sound Observatory (1992), a sonic map that traces the hidden rhythms and sounds of Birmingham; The Desire Paths (1993), a play in which five characters stumble through an apocalyptic urban wasteland with the help of an A to Z; Feet of Memory, Boots of Nottingham (1995), a sound installation documenting the memories of seventy citizens who walked the city in the course of a day; Lost Sound (2001), a film, made in collaboration with John Smith, in which Miller reconstructed his East London neighbourhood from cassette tapes discarded in the street; Dilston Grove (2003), a photosynthetic work, commissioned by the London International Festival of Theatre (LIFT), where Miller's soundtrack accompanied Heather Ackroyd's and Dan Harvey's grass-filled church in Bermondsey, South London; and, most recently, Bassline (2004), which constructs an alternative map of Vienna from the recorded conversations of eleven participants who travelled through the city with a camera while followed by a double-bass player.

Like the performances mentioned above, Linked has no interest in fiction. Its purpose is to offer an alternative history of Miller's neighbourhood in East London, which was ravaged - indeed, literally torn apart - by the construction of the Mi1 link road in the early to mid-1990s. The work, then, is a form of resistance, a sonic memorial to the families who lived in the five hundred houses that were forcibly requisitioned and demolished so that commuters could reach the nearby City of London in time for work.

To combat the amnesia of the present, Miller lined the four-mile route of the link road with twenty transmitters that broadcast a haunting mixture of music, ambient sounds, and personal memories of those who once lived in the now vanished streets. To partake in the performance, the participant borrows a map and a receiver (a headset that looks

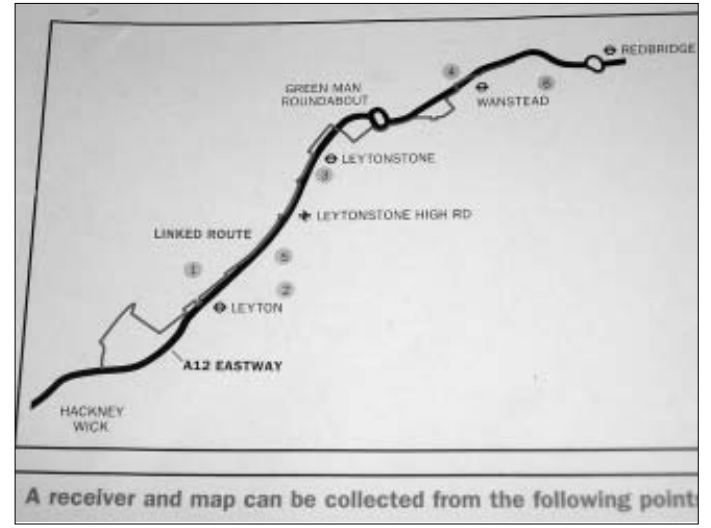

and acts like a Walkman) from one of the local libraries in the boroughs of Hackney and Wanstead, and uses it to navigate his/ her way through the urban landscape' through the urban landscape.

In the publicity that accompanies the work, Linked is defined as 'a landmark in sound, an invisible artwork, a walk'.10 And it is not difficult to understand why. Although the work is rigorously sited - the location is the meaning - the site is absent, situated somewhere in the air above, or the ground beneath, the busy grey tarmac of the new road that rumbles noisily in the near distance. This invisibility, this erasure, is what Miller wants to contest. His sonic memorial haunts the road, reminding those who listen to the personal testimonies on the headset that this anonymous passage de conduite was once a dwelling place, a site of community. By making a visit to the site a prerequisite for the work, Miller transforms his performance into a civic practice in and by itself. To walk Linked is to become a part of the city, a witness to its processes, events, rhythms, and histories.

\section{Performance, Ethnography, and Resistance}

Miller's site-specific work encourages us to engage with the urban environment in which we are placed. Confronted with a performance like Linked, the vocabulary of theatre studies, with its emphasis on script, auditorium, and neat separation between actors and spectators, suddenly seems old, unable to deal with the collapse of boundaries that 
Miller insists on. If the discourse of drama studies can no longer account for Miller's work, then we need to look elsewhere. Ethnography provides a more suitable language for getting to grips with Miller's art. Contemporary ethnography, of the sort practised by James Clifford, is a discipline that tries to understand cultural processes 'from a standpoint of participant observation', 'situated knowledge', and 'self-reflexive writing'. ${ }^{11}$ One way of understanding this self-reflexive and critical form of ethnography is to see it as a form of witnessing through empirical immersion, a means of arriving at the general through the particular, the macro through the micro. ${ }^{12}$

Ethnography's attempt to interpret ways of life and cultural trends through direct observation is exactly what Miller seeks to do when he sends his participants through the East End of London with a map and a headset. ${ }^{13}$ As you walk along the route from Hackney to Wanstead, listening to the testimonies of the evicted and the re-located, it becomes impossible not to think about larger questions to do with life-style, public space, and what it means to be a citizen. To that extent, Miller invites us to practise - to perform - what Marc Augé calls 'an ethnology of supermodernity'. ${ }^{14}$ According to Augé, such an ethnology can only ever be 'an ethnology of solitude', for, in today's society of retail parks, home entertainment systems, and 'real time', the subject is physically isolated from his/her community, and radically alone.

In the influential Non-Places: an Introduction to an Anthropology of Supermodernity (1992), Augé stresses the role that spatial practices have played in the production of supermodern anomie. For Augé, we live at a time in the West when place (the realm of history, identity, and dwelling) has been superseded by non-place (the realm of atemporality, anonymity and passage):

In one form or another, ranging from the misery of refugee camps to the cosseted luxury of fivestar hotels, some experience of non-place (indissociable from a more or less clear perception of the acceleration of history and the contraction of the planet) is today an essential component of all social existence. Hence the very particular and ultimately paradoxical character of what is sometimes regarded in the West as the fashion for 'cocooning', retreating into the self. ... The community of human destinies is experienced in the anonymity of non-place, and in solitude. ${ }^{15}$

If Linked is a performance that encourages its participants to reflect on contemporary spatial practices in the West, it also invites us to think about how that culture experiences time. According to Paul Virilio, the shift from place to non-place that Augé maps is consonant with our addiction to speed - our desire for faster roads, better computer servers, instant communication. In Virilio's view, speed institutes a process of collective forgetting. How can you find time to remember the past when things are so quick that you cannot deal with the present?

As a consequence of our obsession with speed, Virilo argues that we are on the brink of an apocalypse. Citing Walter Benjamin's well-known interpretation of Paul Klee's painting Angelus Nova (1920), Virilio depressingly concludes that 'today this theological vision no longer belongs to the angel of history. It has become the vision of each and every one of us. ${ }^{\prime 16}$

While Miller's work encourages the participant to experience, and then reflect on, the cultural significance of space and time, he is not content to use performance merely to reveal these processes. ${ }^{17}$ He wants to resist them. Speaking of his play The Desire Paths in an interview with the Guardian newspaper in 1993, Miller observes:

We live at a time when people increasingly express the feeling that the world outside our windows is a dangerous and fragmented place. Once upon a time people walked through the city and it gave them a chance to name places and make contact with each other. Each individual has a different map of the city. But humans need to mark their lives against real space and other people. When they cease to walk, the real spaces become less plausible then than the centralized reality of the media and are increasingly witnessed as a passing blur from a car window. They become abandoned, the haunts of the disturbed. ${ }^{18}$

These comments provide an explicit insight into Miller's performance practice. If super- 


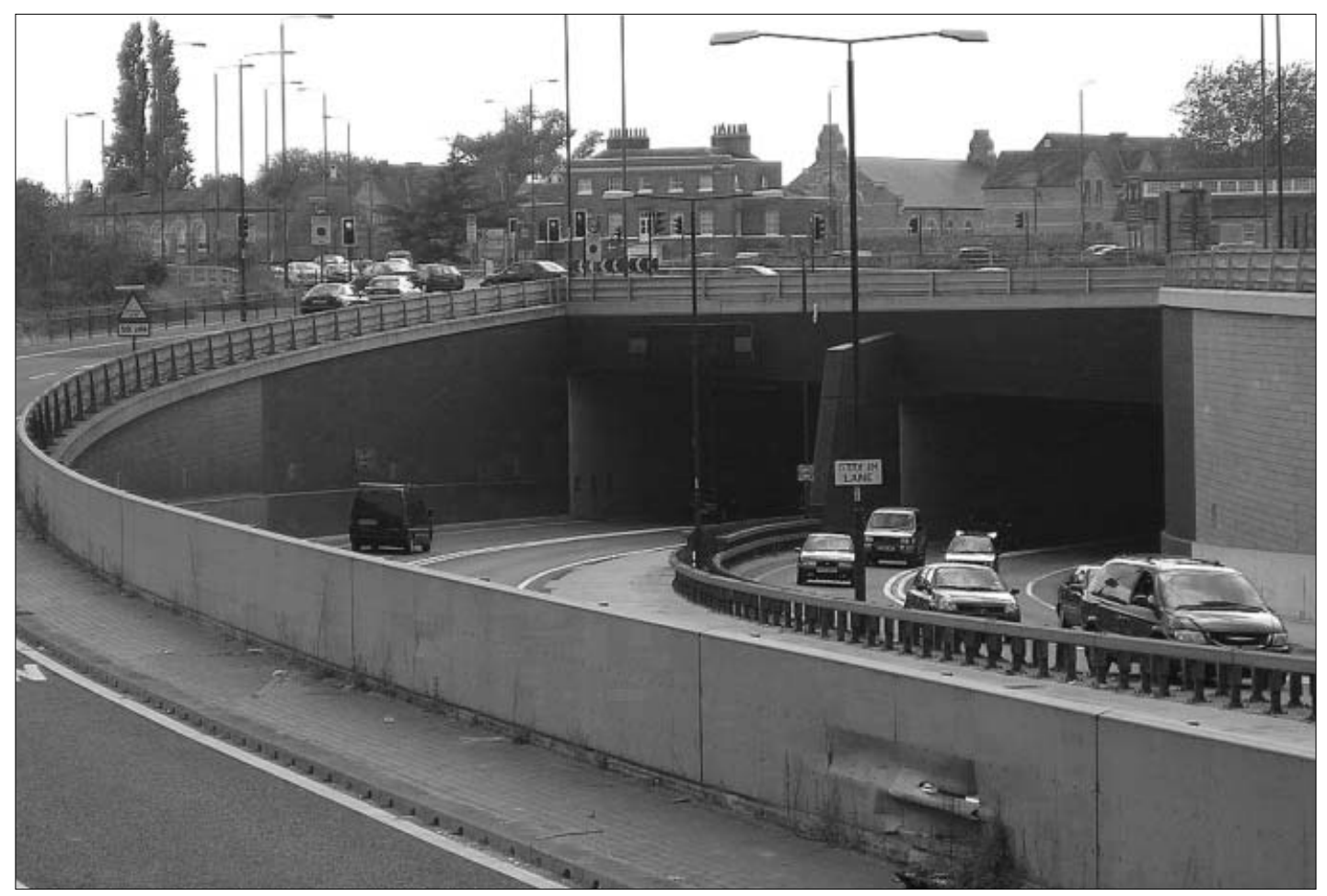

modernity deprives place of memory and community - and what could be more destructive of these things than a motorway? - then performance, Miller argues, ought to find a way of contesting this erasure by providing alternative methods for humanizing space.

Miller underlines his commitment to a politics of lived space in the essay 'Country Dance' (2000). ${ }^{19}$ Crucially in this text he does not define himself as an artist, but as a cartographer interested in making the 'odd map to keep checking out what's what. To remind us that there is complex and subtle life out there. To reveal the singular, ineffable bits. ${ }^{20}$ His performance maps are designed for purposes of resistance. They are meant to reclaim place from the desert of non-place and, in the process, serve as monuments against forgetting. With the help of these maps, the city becomes a site for creative living and affective encounter, not simply something we pass through at top speed.

To that extent, Miller's performance work is part of an avant-garde tradition which, as Peter Bürger argues in Theory of the AvantGarde (1974), attacks the Modernist idea of art as an activity or transcendence divorced from life itself. For Miller, as for Bürger, art is a social praxis:

Having paced around the perimeter of a world which I questioned little and have spent years away from, I sense a yawning gap between Art and Culture. The City is built on the vernacular of shopping and now, Art is too. Art needs to be built on a thriving culture, not on its own ironic view of its own marketplace. Culture is the thick layer; Art the thin - the curious and beautiful distillation. The sooner Art gets itself a Culture on which to rest, the sooner it will feel good to be an artist and the less important whether you are one or not. $^{21}$

\section{The Politics of Pedestrian Performance}

Miller's attempt to re-appropriate urban space for humanist purposes situates his work in the non-heroic terrain of what Henri Lefebvre terms 'everyday life', the space where, in Lefebvre's view, alienation is most keenly felt because of its silent intimacy, its invisible proximity. Philip Wander provides a succinct definition of the Lefebvrian notion of everyday life in his 'Introduction' to the English translation of Lefebvre's key text Everyday Life in the Modern World (1968): 
'Everyday life' refers to dull routine, the ongoing go-to-work, pay-the-bills, homeward trudge of daily existence. It indicates a sense of being in the world beyond philosophy, virtually beyond the capacity of language to describe, that we know simply as the grey reality enveloping all we do. ${ }^{22}$

Despite its seeming inconsequentiality - 'the grey reality enveloping all we do'- everyday life provides a privileged access to political reality. The micro-acts and small-scale experiences that constitute the everyday reflect larger macro-processes that are occurring elsewhere. ${ }^{23}$ The act of driving alone in a car, for

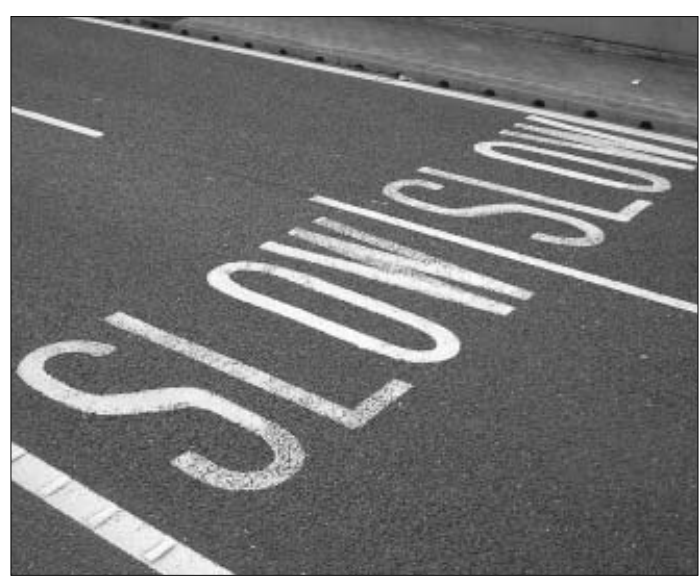

instance, demonstrates the lonely isolation of the contemporary individual better than any theoretical text ever could: it provides empirical proof that supermodern individuality the right to go where we want, when we want - entails separation from others and reinforces solitude.

To assent to that notion of individuality, then, is not just a personal act, it implicates the subject in a network of ideological meanings and assumptions. Or, as Augé puts it, 'never before have individual histories (because of their necessary relations with space, image, and consumption) been so deeply entangled with general history, with history, tout court'.$^{24}$ Yet if everyday life is the space where anomie is experienced concretely, it is equally, Lefebvre claims, the site where that anomie is best resisted. Revolting against the alienation of everyday life - in an urban context, reasserting what Lefebvre claims is our right to the city - is a liberating process: it releases us from the depressing drudgery and invisible discipline that pervades all aspects of everyday life. ${ }^{25}$

Miller's method for using art as an everyday strategy is to rely on the walk. Walking is well suited for this purpose because it allows us, as the French sociologist Michel de Certeau suggests in the influential The Practices of Everyday Life (1974), to see things at ground level and to experience events and sensations that maps and images of the city always miss in their quest for totality and spectacle: ${ }^{26}$

The ordinary practitioners of the city live 'down below', below the thresholds at which visibility begins. They walk - an elementary form of this experience of the city; they are walkers, Wandersmänner, whose bodies follow the thins of an urban text they write without being able to read. ${ }^{27}$

The final line of this passage is important: it informs us that everyday life is not something that can be adequately represented in a text, or read passively at a distance. It is not an object to be consumed, a commodity, a spectacle. On the contrary, everyday life, in de Certeau's terms, is constituted through a series of practices: chance encounters, affective energy-flows, brief conversations, and ephemeral gestures. To get to grips with everyday life, we have to be part of it, to experience it, engage with it. Walking permits this type of embodied knowledge, this form of concrete participation, because it compels the walker to be physically present in the space s/he observes. In this way, everyday life reveals itself through smells, sounds, sights, tastes, intensities, and the rhythms of the body. ${ }^{28}$

As well as being an ideal strategy for witnessing, walking is also productive of everyday life. It is no coincidence, for instance, that de Certeau refers to walking as a speech act, a performative utterance: 'The act of walking is to the urban system what the speech act is to language or to statements uttered. ... It is a spatial acting-out of place. ${ }^{29}$ For de Certeau the city, like signification in general, is neither fixed nor stable: it is brought into being because it is practised, because people walk through it. To walk the city is to rewrite it, to appropriate it for yourself. Thus, no proper, official version 
of the city exists. We all own it:

If it is true that forests of gestures are manifest in the street, their movement cannot be captured in a picture, nor can the meaning of their movements be circumscribed in a text. Their rhetorical transplantation carries away and displaces the analytical, coherent proper meanings of urbanism: it constitutes a 'wandering of the semantic' produced by masses that make some parts of the city disappear and exaggerate others, distorting it, fragmenting it, and diverting it from its immobile order. $^{30}$

The similarities between de Certeau's utopian vision of pedestrianism and Miller's performance practice become evident when we look at how Miller understands the urban environment. Like de Certeau, Miller sees the city in linguistic terms as a text that is endlessly rewritten by the pedestrians moving through it:

Everything is language and makes its own shapes and squiggles. The landscape throws out rushes of calligraphy and is constantly rewriting itself. Every moment we are composing ourselves and our world. A social culture is strings of these compositions which are agreed to be shared. ${ }^{31}$

For Miller, culture is spatial and space is produced through practice. So by sending his participants on a walk through the city, he allows them to engage in an act of poiesis, which, as de Certeau points out, means to 'create, invent, [and] generate'. ${ }^{32}$ In the process, he troubles the logic of a society that associates art with the esoteric activities of 'specialists' (writers, painters, actors), not with the everyday practices of ordinary individuals. Or, to repeat Miller's comments from Country Dance: 'The sooner Art gets itself a Culture on which to rest, the sooner it will feel good to be an artist and the less important whether you are one or not.'

\section{A Note on Representation}

Miller's desire to engage the participant of Linked in a process of creative collaboration has important consequences for the objective writing, the impersonal voice of the third person, which is conventionally associated with academic discourse. For if Miller, like de Certeau, insists that the urban text is produced from the practices of individual Wandersmänner, then how can there be an objective and/or authoritative account of Linked? Surely, everybody will respond to the work differently and rewrite it according to his experiences and/or background?

In order to respect the logic of that position, I have tried to write about Linked, in the pages that follow, as subjectively as possible. I have done so by dividing my account into three separate sections: the way of the stranger; the way of the witness; and the way of the citizen. I use the word 'way' here to refer to (a) an act of walking; (b) a type of experience; and (c) a method of reflection.

This attempt to appropriate language, to write in the first person, is not motivated by a desire to obfuscate or to prevent dialogue. On the contrary, it is intended to enlarge meaning by encouraging the participants of Linked to compare and contrast their experience of the work with mine. The real, the dream of objectivity, is never abandoned. Rather it is re-imagined as something created through active dialogue, through difference. To that extent, my rewriting of Linked is a practice in itself, a method for remaking the everyday. A final point: the ways I have suggested below are my own. Other subjects will discover alternative paths and take different roads.

\section{The Way of the Stranger (Space)}

Linked engaged me in a manner that conventional performance rarely does. Walking the four miles from the Lee Valley Park in Hackney to Redbridge Lane in Wanstead had more in common with an act of pilgrimage than with going to the theatre. There were no actors to gaze at, no building to enter, and no object to consume. The whole purpose of the performance was to bear witness to an act of real destruction, to listen to the voices of the departed, to resist the allconquering claims of car culture.

Linked demands a sacrifice, an investment. You have to walk the route. You are obliged to put in the hours. Your feet suffer. You 
sweat. In a world of pure speed, a world where time is money, the six hours I spent walking, listening, and observing seemed extravagant, wasteful, sacred. I was part of a different economy, acutely aware of how this performance, this walk, was distancing me from the world of work, utility, and speed: the world of the car - the world of the link road. I felt alienated, marginalized, conscious of not working, of taking my time, of doing something different in the city. The performance had efficacy: it affected me. But why did it make me feel so strange?

The performance theorist Allan Kaprow provides a good explanation for this. According to him, performance that erases the boundaries between art and everyday life disturbs us more than performance that insists on maintaining its autonomy from the world. In happenings and invisible performance events, Kaprow argues, objects lose their meaning and migrate from their proper place. We realize then that reality is provisional and that what we do to space affects its meaning, its identity. Since existence is always sited in space and time, this inevitably affects the participant's sense of self:

Such displacements of ordinary emphasis increase attentiveness . . . to the peripheral parts of ourselves and our surroundings. Revealed in this way they are strange. Participants could feel momentarily separated from themselves. ${ }^{33}$

Kaprow was right. When I walked Linked, I felt self-conscious, not at home, 'separated from myself'. London had lost its 'hardness' and 'gone soft'. It had become a dream space, an 'unreal city' ...

The stories I heard on the receiver heightened the strangeness, fed the dream. The sonic skein that Miller spins over the city dislocates consciousness. The memories and sounds entering my ears conflicted with the data processed by my eyes. Where my ears recreated a vanished world of gardens, children playing in the streets, and snow in the city, my eye stubbornly insisted on what was still there: the motorway. Past and present merged; imaginative reality competed with everyday reality.
My disorientation was increased by the performance of the interviewees. Although the testimonies are about the past (hiding out in the Territorial Army Centre in Leytonstone in the 1950s, dancing to soul music at the Flamingo Club in the 1970s, protesting against the link road in the 1990s), they are all delivered as if they were happening just now, in the present. ${ }^{34}$ This suspension of time is estranging: the past haunts the present, doubling it, and ultimately dislocating it from itself. The curator and writer Alan Read experienced a similar blast of strangeness:

Charged with narrative yes, reminiscence maybe, gossip and rumour perhaps, but in Linked there is an invitation to come back down to earth, to walk, to encourage a pedestrian in the presence of the automobile, to engage with two presents. The present that is the first-person narrative of the speaker speaking, now in a present that must have been back then, at least eight years if the words are to be taken at face value. A second present that is the insistent present of the landscape transformed. And between these two presents a tension, held like a refrain from a faraway room, of the sound of memories coming into being just long enough for them to fail again in the forgetting of the insistent demands of time. ${ }^{35}$

Although Read talks of time, the voices on the headset affected me spatially. I had the sensation of belonging to the world and yet being simultaneously outside it. I felt liminal. Neither here nor there, betwixt and between. More attuned to absence (the voices on the headset) than presence (the pedestrians that passed me). I was dislocated.

The strangeness was not all about the voices, though. Throughout the performance I was acutely aware of being an outsider. Wearing a headset, carrying a map, and trying to tune in to a transmitter invariably transforms you into an object of attention Passers-by looked at me strangely, trying to figure me out, seeking to understand what I was doing. In Leyton, a builder eyed me suspiciously as I was trying to tune into a transmitter at the junction between Colville Road and Grove Green Road; in Kingswood Road in Leytonstone, a young woman came out of her house to watch me, and in Wanstead, just off the ironically named Green 


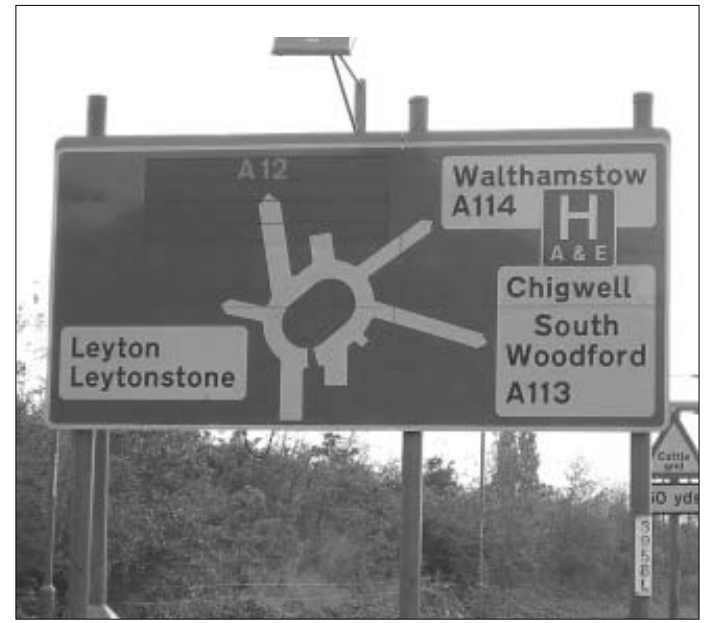

Man Roundabout (there was nothing pagan or green about this roundabout), a mother and her three children scrutinized me sitting under a transmitter. I wondered if these people thought I was a policeman, a Department of Health and Social Security officer, a private detective, or a spy. I had become paranoid, unsure of my place.

In Linked, space is not a passive substance, a mere receptacle. It disorientates; it challenges your perspective on the world; it comes alive. You cannot consume it as a tourist would - that is to say, as an image or as something passive. On the contrary, space affects you; it troubles your ego by positioning you as the stranger, the one who does not belong. ${ }^{36}$ You are catapulted out of the known, forced to leave home, opened to the other. As with every act of pilgrimage, an event takes place in the four miles between Hackney and Wanstead. Something changes, alters, shifts ...

\section{The Way of the Witness (Ethics)}

To perform Linked is to consent to a haunting, to agree to walk in a city of ghosts. The phantasmic voices broadcast by the transmitters weave a dream blanket of memory and reminiscence over the East End. They challenge reality as it is, reminding the solitary walker that the link road which now cuts through the neighbourhood was once filled with streets, houses, and trees, a place where people lived and shared experience.
Listening to these 'foreign correspondents from the past' unhinged me. ${ }^{37}$ I felt melancholic, haunted by absence, surrounded by loss. I imagined the voices taking shape, filling space, living out an existence that had now gone. For all their distance, they seemed intimate, within reach. Their stories touched me. I was responsible for their memories, connected to them.

In the epigram from Spectres of Marx: the State of the Debt, the Work of Mourning, and the New International (1993) which opens this essay, Jacques Derrida talks about the special type of listening required if we are to communicate with ghosts. The striking thing about his injunction is that we are urged not to 'make conversation' with ghosts; rather he wants us 'to let them speak' so that we can discover 'the other in oneself'. For Derrida, the dislocation caused by the passing of the ghost is vital: it gets to the very core of ethics, which, in his view, is bound up with notions of inheritance and witnessing:

That we are heirs does not mean that we have or that we receive this or that, some inheritance that enriches us one day with this or that, but that the being of what we are is first of all inheritance, whether we like it or know it or not. And that, as Hölderin said so well, we can only bear witness to it. To bear witness would be to bear witness to what we are insofar as we inherit and that - here is the circle, here is the chance or finitude - we inherit the very thing that allows us to bear witness to it. ${ }^{38}$

Derrida's ideas provide a useful perspective on why Linked exerts such a strong if uncanny ethical pull. For if we accept Derrida's argument that the ghost's capacity to alter subjectivity is what transforms us from disinterested spectators into witnesses, then by placing us in contact with spectres, in this context, with people and places that are no longer there, Miller raises questions of value and justice. In Derrida's terms, he asks the naive, yet crucial question, of how to live.

Someone, you or me, comes forward and says: I would like to learn to live finally. . . . To learn to live: a strange watchword. Who would learn? From whom? To teach to live, but to whom. Will we ever know? Will we ever know how to live and first of all what to 'learn to live' means? And why 'finally'? 
In Linked, blunt questions have far-reaching consequences. I started to see the link road as something emblematic, which, like the purloined letter in Edgar Alan Poe's famous short story, conceals the very thing it makes manifest. Why, for instance, are individuals and communities routinely sacrificed for greater ease of access? Why this addiction to speed? Why the car? Why profit? How did we reach this point? Because it poses these questions, Linked stands as the conscience of capital, a performance that keeps the past alive, marking the traces of the dispatched and disappeared.

However, while Linked pays witness to what has gone, it is no exercise in nostalgia. I felt uplifted after walking Linked. As I left to take my train back to Kings Cross, the small pedestrianized square in front of Leytonstone Tube Station heaved with people in a riot of language and colour. The neighbourhood was on the mend, healing itself from the wounds inflicted by the road a mere fifty metres away across the bridge. This renewal of language, this rediscovery of community, is what Miller wants his spectral art, his conjuring trick, to contribute to:

We read and write ourselves into the landscape, our own narrative overlapping with our neighbours. Yet I cannot fit my house back into its footprint (now space above the road). It is a surface that will no longer host my decade of life in Grove Green Road. As the particles of speech of Linked face the future there lies a hope that they will connect with triggered rememberings, counter-stories, and gross omissions and alternative versions of the same event that may renew the narrative tissue of the neighborhood. ${ }^{40}$

The futural hope that Miller places in memory, in the dislocated time of the spectre, brings to mind Derrida's claim in Spectres of Marx that to 'talk with or about some ghost' is to 'ask the question "where?", "where tomorrow?", "whither?" 41 By inviting us to speak to ghosts, Miller opens his work to a different absence the absence of those who have still to inherit. For reasons such as these, Linked can be profitably seen as a work of mourning. The sadness it evokes is galvanizing, producing what Avery Gordon calls 'transformative recog-

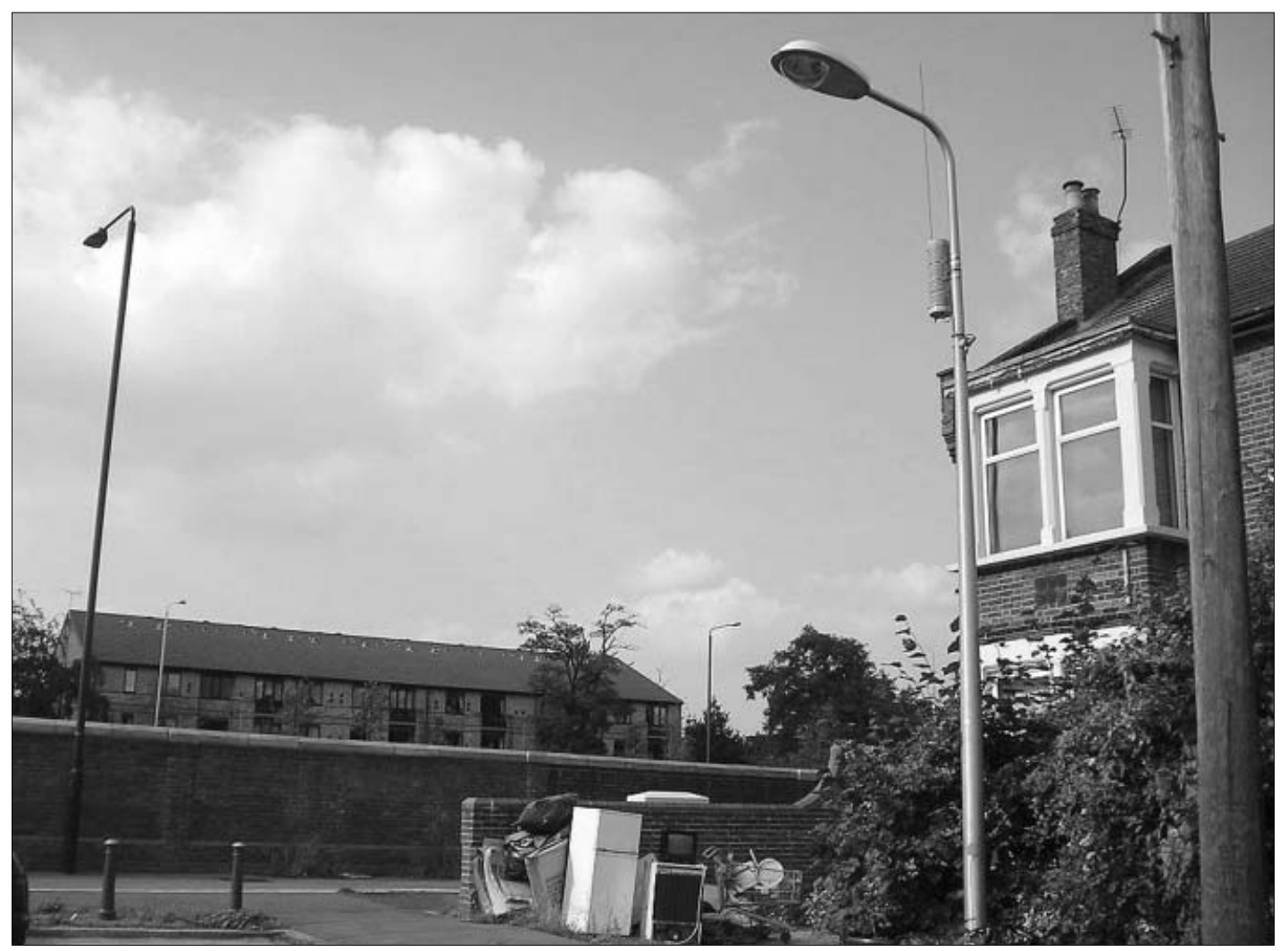




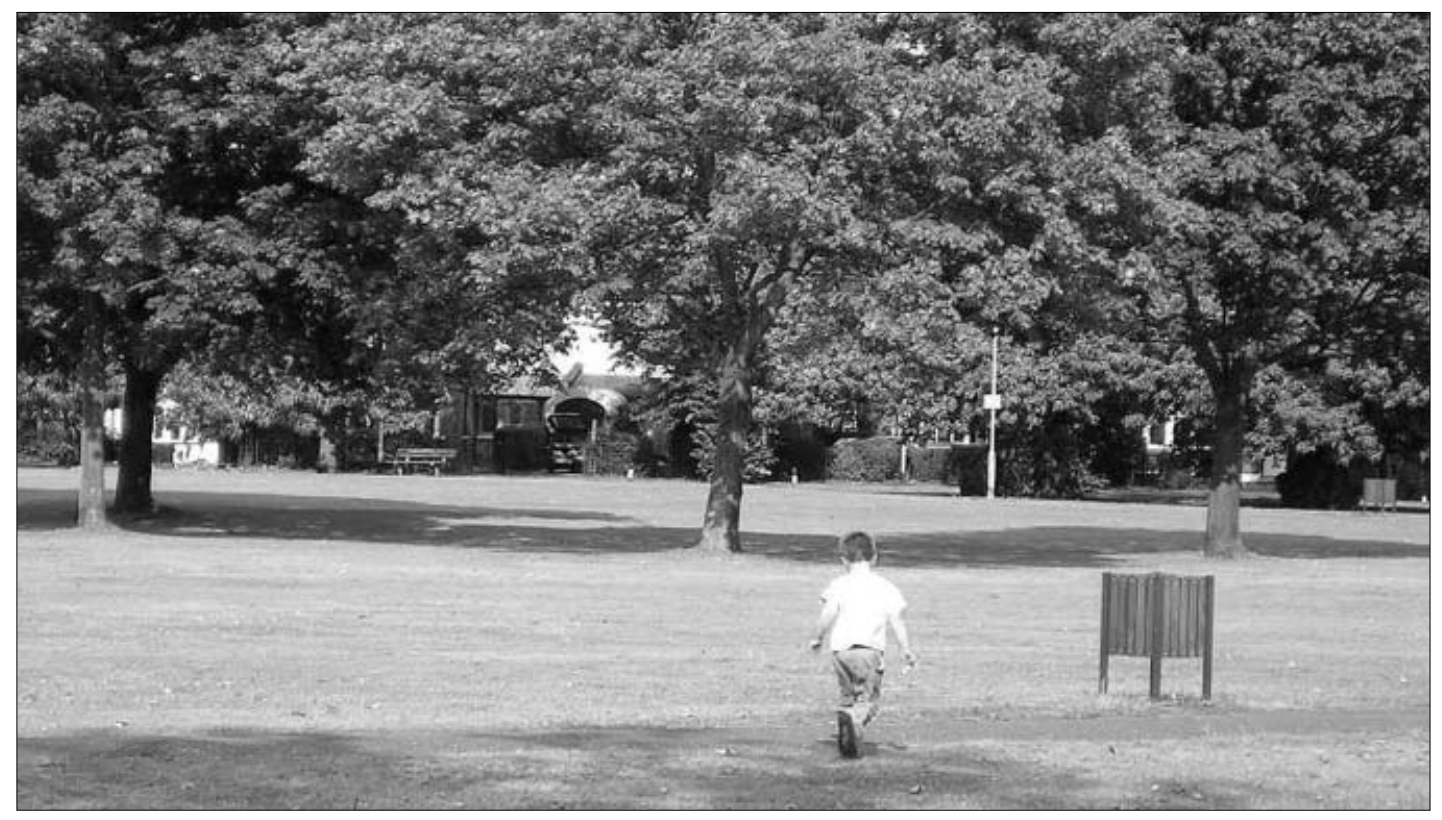

Ways of the stranger and of the citizen. Opposite page: Blake Road (note the transmitter on the lamp post on the right of the picture). Above: Wanstead Common.

nition'. ${ }^{42}$ That is, recognition that alters the community allowing it to become something new, something different.

\section{The Way of the Citizen (Politics)}

Linked is a profoundly political piece that bears witness to the attempts of the local community and a dedicated band of ecowarriors to block the construction of the M11 link road in the early to mid-1990s. Like The Battle of Orgreave (2001), Jeremy Deller's reenactment of the pivotal clash between the miners and the police in the strike of 1984, Linked offers an alternative perspective on recent history: it reminds the listener that debate and protest, despite the claims of neoliberal thinkers, have not disappeared in the last twenty years and that reality is still open to debate and change. The utopianism of the period is evident in the narrative of an activist who told how the local postman continued to deliver letters to his tree-house during the protests and how a retired RAF pilot, living in the houses opposite the common, left him half-bottles of whisky when it was cold.

Despite the failure of the protests - the presence of the link road is an all-too con- stant reminder of that - I was impressed by the exuberance and fortitude in the voices of the people recorded. It was apparent that the protest movement had been a defining moment in their lives. Deciding to resist government policy had politicized them, empowered them, made them more daring. The transmitter that stands sentinel on Wanstead Common, for instance, broadcasts the story of Jean, the Welsh lollipop lady, who, along with local schoolchildren and teachers, stopped the contractors from destroying a two-hundred-and-fifty-year-old chestnut tree on the common. Participating in a communal action allowed local residents like Jean to escape from the isolation of their living rooms - what Marc Augé calls 'cocooning' and to constitute themselves as a civic body, a community. For citizens of the short-lived republics of Wanstonia and Leytonstonia, the city was exactly what the non-space of the link road was about to threaten: a public realm, a space where strangers were not only encountered but embraced. ${ }^{43}$

As I listened to these narratives, I became conscious of how they contradicted the spectacular images of metropolitan life that represent the inner city as a jungle, a landscape 
of danger and fear. In Linked, by contrast, the streets of Hackney and Wanstead are remembered by people who lived there as sites of openness and civility. To that extent, Linked echoes Jane Jacobs's warning about car culture in her classic book The Death and Life of Great American Cities: the Failure of Town Planning (1961). According to Jacobs, cities are not dangerous because they are filled with masses of strangers; rather, they are dangerous when they prevent people from meeting:

Streets in cities serve many purposes besides carrying vehicles.... Streets and their sidewalks, the main public places of a city, are its most vital organs. ... To keep the city safe is a fundamental task of a city's streets and its sidewalks. ${ }^{44}$

Jacobs's comments underline the sophistication of Miller's performance practice. Linked is not simply a political work because it represents an actual political event: its political value resides, ultimately, in its practical dimension. In Linked, stopping for a coffee, asking for directions en route, and buying food and water in local shops are significant acts: they provide an opportunity for conversation. And, as de Certeau reminds us, conversation is what socializes space:

Conversation is a provisional and collective effect of competence in the art of manipulating 'commonplaces' and the inevitability of events in such a way as to make them 'habitable'. ${ }^{45}$

\section{A Paradigm for Political Performance}

The speech that Linked inevitably gives rise to reveals the political essence of civitas to be neither dependent on juridical law nor on ideological consistency, but rather on our ability to live with - and respect - others who are not affiliated to us by ties of kinship or substantive notions of community (Gemeinschaft). In this way, Linked practises what the urban sociologist Richard Sennett has argued in numerous publications from The Fall of Public Man: on the Social Psychology of Capitalism (1974) to Respect in a World of Inequality (2003): namely, that city living, the politics of the polis, is grounded in our ability to live with strangers in public spaces that encourage encounter and debate.
In the pages above, I have responded to Miller's invitation to rewrite Linked from a personal perspective. I have done so by stressing the existential, ethical, and political significance it had for me. In the final section, I want to argue that Linked's practical dimension - the fact that the everyday is experienced as an empirical event - offers an alternative paradigm that has much in common with the aesthetic and political programme of the Situationists.

For the Situationists, art is neither a vicarious experience nor a mere functional tool. Rather, art - and in particular theatre - has the capacity to explode the logic of the society of the spectacle, which, according to Guy Debord, Situationism's main theorist, is based on the twin evils of separation (keeping people apart) and specialization (perpetuating hierarchies of people). Art that has renounced the page, stage, and gallery has the potential to be a revolutionary practice, argues Debord, because, in an age of abundance, cultural production is more important than economic production. ${ }^{46}$ In a post-industrial, service economy, the crucial battle is for the mind of the masses, and this battle, Debord maintains, takes place at the level of the spectacle, the image: 'The spectacle is not a collection of images; rather, it is a social relationship between people that is mediated by images. ${ }^{47}$

In the society 'mediated by images', spectatorship is politically reactionary, for it is this activity, above all else, claims Debord, that produces alienation and isolation:

The spectacle's externality with respect to the acting subject is demonstrated by the fact that the individual's own gestures are no longer his own, but rather those of someone else who represents them to him. ${ }^{48}$

If controlling cultural consumption, situating the subject as spectator, is the essence of political domination, then activating cultural production on a mass scale, producing a society of performers, is, Debord believes, the key to cultural and political change. For how can the spectacle function if the masses prefer to remake the world actively rather than to watch it passively on the screen or monitor in front of them? 
Debord contends that this shift from consumption to production can occur by subjecting everyday life to a process of détournement or imaginative hijacking. Situationists attempt to détourner the world by creating situations - public performances - that subvert reality from the inside, in the here and now. The crucial point about détournement is that art is not used to transcend the everyday; rather the everyday is used to transcend art. Or to put it differently: to live is to create and to create is to live. There is no need for a product or commodity, no space for a spectacle.

The notion of détournement describes, with some accuracy, what Miller is trying to do in Linked. By installing transmitters on a fourmile stretch of the Mi1 link road and inviting participants, many of whom are strangers to the area, to walk the route, Miller transforms a motorway into a work of art, a site where imaginative production takes place. In the process, he re-appropriates space (the place of encounter and dialogue) from the desert of non-space (the isolation caused by cars on a motorway).

The everyday is no longer a site of misery but a source of creativity. Just as importantly, the separation caused by the motorway - the fact that it physically blocks communication with other people - has been used to develop new forms of encounter with Wandersmänner who drift through the local community and produce social space with every step they take. Linked is a situation, an act of creative reclamation, a pedestrian performance that blurs the boundaries that link art and everyday life. To repeat a refrain from Miller that has run throughout this essay:

The sooner Art gets itself a Culture on which to rest, the sooner it will feel good to be an artist and the less important whether you are one or not...

\section{Notes and References}

I would like to thank Franc Chamberlain, Nicholas Whybrow and Ralph Yarrow for commenting on earlier drafts of this essay. Original dates are given in the main body of the text; dates of the editions I used are given in the notes.

1. Graeme Miller, 'Country Dance', in Alan Read, ed., Architecturally Speaking: Practices of Art, Architecture, and the Everyday (London: Routledge, 2000), p. 109-17 (117).
2. Stanton B. Garner, Jr, 'Urban Landscapes, Theatrical Encounters: Staging the City', in Elinor Fuchs and Una Chaudhuri, eds., Land/Scape/Theater (Ann Arbor: University of Michigan Press, 2002), p. 94-118 (96).

3. Jacques Derrida, Spectres of Marx: the State of the Debt, the Work of Mourning, and the New International, trans. Peggy Kamuf (London: Routledge, 1994), p. 176.

4. Jane Jacobs, The Death and Life of Great American Cities: the Failure of Town Planning (London: Penguin, 1972), p. 352.

5. Henri Lefebvre, Rhythmanalysis: Space, Time, and Everyday Life, trans. Stuart Elden and Gerald Moore (London: Continuum, 2004).

6. Cornelia Barker, Linked (London: Arts Admin, 2003), p. 2.

7. Note the comments of Cathy Ross, of the Museum of London, in Linked (p. 3): 'Linked will be the first site-specific artwork to enter the Museum's collections, but it is by no means our first piece of contemporary art. For the last fifteen years or so the Museum has been actively collecting what might be called 'urban art', work in some way engaged with the contemporary city. These works are collected very much as art, rather than topography, in that what the Museum looks for is an artist's subjective and individual vision of the city, rather than any objective record of what things looked like.'

8. I use the word performative here in the sense of Peggy Phelan's notion of performative writing which approaches performance from a joint theoretical and autobiographical perspective. See Peggy Phelan, Mourning Sex (London: Routledge, 1997). For a concrete example of performative writing, see Phelan's essay, 'On Seeing the Invisible: Marina Abramovi's The House with the Ocean View, in Live: Art and Performance, ed. Adrian Heathfield (London: Tate Publishing, 2004), p. 16-27.

9. See Linked, p. 16.

10. See <http:/ / www.LinkedMi1.net>.

11. James Clifford, The Predicament of Culture: Twentieth-Century Ethnography, Literature, and Art (Cambridge, MA: Harvard University Press, 1988), p. 9.

12. Speaking about how the modernist poet William Carlos Williams influenced his understanding of ethnography , Clifford notes: 'Williams's Paterson became a model, a provocation for a new kind of realism. This was situated knowledge, freed from the constraints of scientific objectivity and the Lukácsian "type", a path through even the most particular and subjective facts to a kind of general view, a "big enough" vision.' See James Clifford, 'An Ethnographer in the Field: James Clifford Interview', in Alex Cole, ed., Site-Specificity: the Ethnographic Turn (London: Black Dog, 2000), p. 52-71 (54).

13. This type of ethnography escapes the authoritarianism inherent in older anthropological models. Here, there is no desire to create a scientific object, existing beyond the observer: rather, it assumes that the observer is implicated in the production of knowledge, and, for that reason, offers an always already partial. Hence the emphasis on self-reflexivity.

14. Marc Augé, Non-Places: an Introduction to an Anthropology of Supermodernity, trans. John Howe (London: Verso, 1995), p. 120.

15. Augé, p. 119-20.

16. Paul Virilio, A Landscape of Events, trans. Julie Rose (London: MIT Press, 200o), p. xii. Virilio's comments are based on the following remarks from Benjamin: 'A Klee painting named "Angelus Novus" shows an angel looking as though he is about to move away from some- 
thing he is fixedly contemplating. His eyes are staring, his mouth is open, his wings are spread. This is how one pictures the angel of history. His face is turned toward the past. Where we perceive a chain of events, he sees one single catastrophe which keeps piling wreckage upon wreckage and hurls it in front of his feet.' See Walter Benjamin, 'Theses on the Philosophy of History', in Iluminations: Essays and Reflections, trans. Harry Zohn, ed. Hannah Arendt (New York: Shocken, 1969), p. 25364 (257).

17. Miller's performances are interventions in actual space and time. They encourage participation and activation. To that extent, they differ from ethnography's page-bound critique. I am thinking here, in particular, of Marc Augé's essay, 'An Ethnologist in Disneyland', in Site-Specificity: the Ethnographic Turn, trans. Alexia Defert, p. 182-91.

18. Graeme Miller, The Guardian, 15 June 1993, p. 28 19. This essay is a companion piece to Miller's production Country Dance (1999), a play that 'was conceived as a stage work about Dance, rather than as a dance work in itself'. See <http://www.mdx.ac.uk/rescen/ Graeme_Miller/country.html>.

20. Miller, 'Country Dance', p. 116

21. Ibid., p. 115.

22. Philip Wander 'Introduction', in Henri Lefebvre, Everyday Life in the Modern World, trans. Sacha Rabinovitch (London: Transaction, 2002), p. vii-viii.

23. Lefebvre notes:

The everyday can therefore be defined as a set of functions which connect and join together systems that might appear to be distinct. . . . A condition stipulated for the legibility of forms, ordained by means of functions, inscribed within structures, the everyday constitutes the platform upon which the bureaucratic society of controlled consumerism is erected.

See 'The Everyday and Everydayness', trans. Christine Levich, Alice Kaplan, and Kristin Ross, in Alice Kaplan and Kristin Ross, ed., Everyday Life, Yale French Studies, LXXIII (1987), p. 7-11 (9).

24. Augé, p. 119-20.

25. The urban sociologist Franco Bianchini defines four ways by which everyday alienation undermines creative living in the city: 'the dispersal of urban functions; the emergence of "non-places"; the reduction of leisure time for people in work; and the consequences of "information overload" and of the "audit explosion". See 'A Crisis in Urban Creativity? Reflections on the Cultural Impacts of Globalization, and on the Potential of Urban Cultural Politics', paper presented at the International Symposium, 'The Age of the City: the Challenge for Creative Cities', Osaka, 7-10 February 2004.

26. Benjamin Rossiter and Katherine Gibson also stress the politics involved in pedestrian performance in their essay about the live performance The Urban Dream Capsule, performed by five 'art-stronauts' at the Melbourne International Arts Festival in 1996. They conclude their essay thus: 'The poetics of walking permits encounters with city fragments and seemingly "unimportant" urban activities - the practices of urbanism that are not neatly folded into forceful stories of capitalist urbanization, social polarization, urban consolidation, and dead-city syndrome.' See Benjamin Rossiter and Katherine Gibson, 'Walking and Performing "The City": a Melbourne Chronicle', in A Companion to the City, ed. Gary Bridge and Sophie Watson (Oxford: Blackwell, 2003), p. 437-47 (445-6)

27. Michel de Certeau, The Practice of Everyday Life, trans. Steven F. Rendall (Berkeley: University of California Press, 1984), p. 93.

28. This is also how Lefebvre believes that everyday life gives up its secrets. For him, the 'truth' of the everyday is communicated in murmurs, sounds, and, especially, rhythms. See 'Elements of Rhythmanalysis: an Introduction to the Understanding of Rhythms' in Rhythmanalyis: Space, Time, and the Everyday, p. 1-69.

29. De Certeau, p. 97.

30. Ibid., p. 102.

31. Miller, 'Country Dance', p. 116.

32. De Certeau, p. 205.

33. Allan Kaprow, quoted in Sarah Gorman, 'Wandering and Wondering: Following Janet Cardiff's Missing Voice', Performance Research, VIII, No. 1 (2003), p. 83-92 (89).

34. The experience is not dissimilar to what Walter Benjamin calls Jetztzeit: a messianic moment that stops the flow of history. According to Benjamin, messianic time 'blasts' open 'the continuum of history' - and for that reason, it has the potential to deliver us from suffering, which, in Benjamin's opinion, teleologically driven notions of history are unable to do. See Benjamin, p. 261.

35. Alan Read, Linked, p. 5

36. For a good account of how the tourist consumes space, see John Urry, Consuming Places (London: Routledge, 1995).

37. Miller, Linked, p. 2.

38. Derrida, p. 54 .

39. Ibid., p. xvii.

40. Miller, Linked, p. 2.

41. Derrida, p. viiii-ix.

42. Avery Gordon notes: 'Being haunted draws us affectively, sometimes against our will and always a bit magically, into the structure of feeling we come to experience, not as cold knowledge, but as a transformative recognition.' See Avery F. Gordon, Ghostly Matters: Haunting and the Sociological Imagination (Minneapolis: University of Minnesota Press, 1997), p. 8.

43. As a form of protest against the government's refusal to listen to the democratic demands of its citizens, the free republics of Wanstonia and Leytonstonia were declared in January and February 1994.

44. Jacobs, p. 39

45. de Certeau, p. xxii

46. Alice Kaplan and Kristin Ross stress this aspect of Situationism: 'Staying within a specifically Marxist vocabulary, we might say that the Situationists shifted their attention from the relations of production within the factory to that basic yet undertheorized problem of social reproduction ... what we are here calling everyday life.' See Alice Kaplan and Kristin Ross, 'Introduction', in Everyday Life, p. 1-4 (2).

47. Guy Debord, trans. Donald Nicholson-Smith, The Society of the Spectacle (New York: Zone, 1995), p. 12. 48. Debord, p. 23. 